\title{
Could the Three Be Edible and Natural Sources of Levodopa? Morphological Characterization of Three Taxa of Mucuna (Fabaceae) in Ebonyi State, Southeastern Nigeria
}

\author{
O.E. Nwankwo, S.A. Odewo, B.A. Ajani, L.T. Soyewo, M.S. Nwefuru
}

10.18805/ag.D-320

\begin{abstract}
Background: There were reports that $M$. pruriens was edible and natural source of Levodopa used in the treatment of Parkinson's disease, but the identity of the variety used for the treatment is uncertain. Hence, the present study is important to provide their diagnostic characters for further studies by prospective researchers.

Methods: The qualitative study was carried out by observing and recording the features of the taxa while the quantitative was obtained as the leaflet length and width were measured using a metre rule. From each specimen, leaves were randomly selected and measured using metre rule. Standard methods were used in this study.

Result: The three taxa possess trifoliate leaves in common and the flower colours are as follows: Yellow in $M$. flagellipes, purple in $M$. puriens var. pruriens and white in $M$. pruriens var. utilis. Testa colours are black, black and white in the M. flagellipes, M. pruriens var. pruriens and $M$. pruriens var. utilis, respectively. The highest average leaflet length was 17.5 recorded in $M$. pruriens var. pruriens while the lowest average leaflet length of 8.4 was recorded in $M$. pruriens var. utilis. The three taxa could be eaten based on review. Petal and testa colour could be used to distinguish the taxa studied.
\end{abstract}

Key words: Diagnostic characters, Edible, Levodopa, Morphological characterization, Petal, Testa, Variety.

\section{INTRODUCTION}

Species of Mucuna Adans are legumes in the tribe phaseoleae (Natarajan et al., 2012). The species are climbing vines and erect shrubs distributed worldwide. According to Natarajan et al. (2012) the genus Mucuna contains about 120 species while De Moura et al. (2016) reported 115 species in the genus distributed world-wide with 19 species occurring in Africa. It is native to India and China and has the character of high diseases resistance and grows well in dry soil with low fertility condition (Ravishankar et al., 2016). They possess mainly trifoliate leaves (De Moura et al., 2016). Mucuna flowers show a remarkable variation in colour of the corolla, ranging from white (M. pruriens) to black (Tozzi et al., 2005). Based on fruit and seed morphology, two subgenera which are Mucuna subg. Mucuna and Mucuna subg. Stizolobium (P. Browne) Baker have been traditionally recognized in Mucuna (Wilmot-Dear, 1984). Most of the Mucuna species have wide economic importance in agriculture as forage and green manure, weed biological control and as a coffee substitute (Ravishankar et al., 2016). Ukachukwu and Obioha (2000) reported that rural population of Nigeria consume seeds of Mucuna cochinchinensis during scarcity of common legumes. Osei-Bonsu et al. (1996) also reported that $M$. cochinchinensis and $M$. utilis are used as soup thickeners in Southern Ghana as the soup is eaten along with starchy food. Seeds of Mucuna urens are used as soup thickener and vegetable oil by Igbo community of Southeastern Nigeria (Afolabi et al., 1985; Ukachukwu
Department of Applied Biology, Ebonyi State University, Abakaliki Nigeria.

Corresponding Author: O.E. Nwankwo, Department of Applied Biology, Ebonyi State University, Abakaliki Nigeria.

Email: ephraimnwankwo8@gmail.com

How to cite this article: Nwankwo, O.E., Odewo, S.A., Ajani, B.A., Soyewo, L.T. and Nwefuru, M.S. (2021). Could the Three Be Edible and Natural Sources of Levodopa? Morphological Characterization of Three Taxa of Mucuna (Fabaceae) in Ebonyi State, Southeastern Nigeria. Agricultural Science Digest. DOI: 10.18805/ag.D-320.

Submitted: 06-11-2020 Accepted: 15-06-2021 Online: 01-09-2021

et al., 2002). Seeds of M. sloanei and M. flagellipes Hook.f. are cracked by hitting with a hard object before cooking, then hulled, ground, mixed with red palm oil to obtain yellow powder and marketed as soup thickener (Ezueh, 1997). Consumption of Mucuna as food has also been reported from Mozambique and Malawi (Infante et al., 1990; Gilbert, 2002). According to Adebowale and Lawai (2005) and Ezeagu et al. (2003), Mucuna species generally have high protein content of $24 \%$ to $1.44 \%$, lipids ranging from $2.86 \%$ to $9.8 \%$, crude fibre (5.3-1.5\%), ash (2.9-5.5\%) and carbohydrate ranging from $59.2 \%$ to $64.88 \%$. The antinutritional factors found in Mucuna species include L-dopa, phenolics, tannin, haemagglutinins, trypsin and chymotrypsin inhibitors, phytic acid, saponins and cyanogenic compounds (Vadivel and Janardhanan, 2000). However, most of these anti-nutritional factors are eliminated 
Could the Three Be Edible and Natural Sources of Levodopa? Morphological Characterization of Three Taxa of Mucuna...

to low levels during processing. Ukachukwu and Obioha (1997) reported detoxification by cooking for 90 minutes or toasting for 60 minutes. The studies of Ravishankar, et al. (2016) on genetic relationship of $M$. macrocarpa, $M$. imbricata and two hybrids named as IIHR hybrid and Dhanwantari showed that $M$. macrocarpa was genetically close to $M$. atropurpurea and $M$. gigantea whereas $M$. imbricata and hybrids IIHR hybrid and Dhanwantari were genetically more close to two varieties of $M$. pruriens which are var. pruriens and var. hirsuta.

Mucuna pruriens (L.) DC. is commonly known as 'Velvet bean'. It is native to Africa and Asia with a vigorous climbing habit. The velvet bean has long, slender branches, alternate leaf arrangement, lanceolate leaf shape; and white flowers with a bluish-purple butterfly-shaped corolla. The pods of $M$. pruriens are pubescent and contain 4 to 6 seeds (Lampariello et al., 2012). There are varieties of $M$. pruriens which are var. pruriens and var. utilis. Mucuna pruriens is by far the most investigated species for the study of intra species genetic and chemo-diversity. Mucuna pruriens is the source of an established herbal drug used for the management of Parkinson's disease, male infertility, nervous disorders and also as an aphrodisiac. It has been shown that its seeds are of high medicinal importance (Lampariello et al., 2012). It is the natural source of levodopa in large amounts used mostly for the treatment of Parkinson's disease (Maldonado, 2018).

Agharkar (1991) and Singh et al. (1996) reported that $M$. pruriens is a constituent of more than two hundred indigenous drug formulations. It is widespread and common in bushes and low forests areas of India. All parts of $M$. pruriens are importantfor medicine (Pandey, 1999). Mucuna pruriens roots are bitter, thermogenic, anthelmintic, diuretic, emollient, stimulant, aphrodisiac, purgative, febrifuge, tonic, etc. It is considered useful to relieve constipation, nephropathy, strangury, dysmenorrhoea, amenorrhoea, elephantiasis, dropsy, neuropathy, consumption, ulcers, helminthiasis, fever and delirum (Shalini, 1997; Upadhyay, 2000). Leaves are popular culinary herbs and fodder crops which are useful in the treatment of ulcers, inflammation, cephalagia and general debility. The trichomes of Mucuna pods contain mucuna in and serotonin and as a result, pod causes itching, blisters, and dermatitis. Pods are also used as vegetable and pod hairs (trichomes) are used as anthelmintic. Hairs mixed with honey have been used as vermifuge. As ointment prepared with hairs act as a local stimulant and mild vesicant (Shastry, 1995). Besides, medicinal properties, Mucuna fixes nitrogen and is as a green manure and cover crop. Seeds contain L-DOPA (4-3, 4-dihydroxy phenylalanine), glutathione, lecithin, gallic acid, glycosides, nicotine, prurenine, prurenidine, dark brown viscous oil. Demand for M. pruriens increased in Asian drug markets and internationally after the discovery that Mucuna seeds contain L-dopa, an anti-parkinson's disease drug (Farooqi, 1999). Ravishankar et al. (2016) stated that there was paucity of information on phylogeny with high degree of taxonomical confusion in the genus Mucuna. Besides, it is uncertain which variety of $M$. pruriens is the source of natural Levodopa used in the treatment of Parkinson's disease.

\section{Cultivated varieties of $M$. pruriens}

There are four cultivated varieties Mucuna pruriens which are: $M$. pruriens var. pruriens, $M$. pruriens var. hirsuta (Wight and Arn.) Wilmot-Dear, M. pruriens var. sericophylla (Perkins) Wilmot-Dear, M. pruriens var. utilis (Wall. ex Wight) Baker ex Burck (Buckles, 1995; https://www.tropicalforages.info/ pdf/mucuna_pruriens.pdf ). These varieties are distributed worldwide. The commonest among all varieties are var. pruriens and var. utilis ((Eilitta et al., 2003). The basionym $M$. pruriens var. utilis has other nomenclature based on the perceptions of other authors. Some synonyms of $M$. pruriens var. utilis are: Carpopogon capitatus Roxb, Macranthus cochinchinensis Lour, Mucuna aterrima Holland, Mucuna pruriens var. biflora Trimen, Mucuna deeringiana (Bort) Merr (Eilitta et al., 2003). Fruits of Mucuna pruriens var. utilis have long pale silky hairs with seeds often streaked in different colours while fruits of Mucuna pruriens var. pruriens have orange-brown irritant bristles with seeds uniform in colour (Carsky et al., 1998).

Mucuna flagellipes is a legume popularly known as 'ukpo' by the Igbo-speaking people of Southeastern Nigeria (Enwere, 1998). It possesses pods containing 1 to 3 seeds with a hard coating which is white when immature and turns black when mature and dry (Enwere, 1998). Mucuna flagellipes is a liana of high economic importance (Ezueh, 1997). It is very useful in Southeastern Nigeria as a soup thickener. Using the seeds involves cracking, boiling, deshelling and grinding the seeds to powder before adding to thicken the soup. In some villages, the seeds are special delicacy. The cracked seeds are spiced to taste and served as a delicious meal. (Ezueh 1997; Eneobong and Corovale, 1992). The seed flour of $M$. flagellipes is used as soup thickener in most Igbo-speaking communities of Southeastern Nigeria. Preparation of the seed is usually associated with long cooking time which is required to soften the cotyledon before grinding as well as reduce the anti-nutritional components of the seed (Onuegbu et al., 2003).

\section{Toxicity of the Mucuna grains}

Mucuna grains can be toxic for human and non-ruminant animals if consumed when the anti-nutritive substances in them are untreated. The most important toxic compounds are the non-protein amino acids, L-dopa and hallucinogenic tryptamines. Grain treatment has best been done by boiling in water for one hour, pressure-cooking for 20 minutes, or boiling in water for 30 minutes after soaking in water for 48 hours. Despite the presence of anti-nutritional compounds however, there is evidence that velvet bean grains can be fed to ruminant animals to supplement their diet without apparent problems (https://www.tropicalforages.info/pdf/ mucuna pruriens.pdf; Onuegbu et al., 2003). 


\section{MATERIALS AND METHODS}

Fresh specimens of $M$. flagellipes $M$. pruriens var. pruriens and $M$. pruriens var. utilis were collected from different locations in Southeastern Nigeria and identified in Ebonyi State University Herbarium, Abakaliki, Nigeria. The voucher numbers are: EBS-H-0231, EBS-H-0232 and EBS-H-0233 respectively. The qualitative and quantitative characters of the taxa were studied following the method used by Nwankwo and Ayodele (2017). The qualitative study was carried out by observing and recording the features of the taxa while the quantitative was obtained as the leaflet length and width were measured using a metre rule. From each specimen, leaves were randomly selected and measured using metre rule.

\section{RESULTS AND DISCUSSION}

The results of this study showed that the taxa possess trifoliate leaves and tubular flower shape in common. The flower colours are yellow in $M$. flagellipes, purple in $M$. puriens var. pruriens and white in M. pruriens var. utilis. Testa colours are black in $M$. flagellipes and $M$. pruriens var. pruriens while in $M$. pruriens var. utilis it is white. The leaflet length of the taxa are $6.4(9.5 \pm 0.20) 11.2,13.0(17.5 \pm 0.1) 24.1$ and $9.0(8.4 \pm 0.1) 13.2$ in $M$. flagellipes, $M$. pruriens var. pruriens and $M$. pruriens var. utilis, respectively. The highest average leaflet width of 12.3 was recorded in $M$. pruriens var pruriens while the lowest average width 4.9 in $M$. flagellipes. The result is summarized in Table 1 and 2 while the photographs of the taxa are shown in Fig 1.

Mucuna flagellipes is closely related to $M$. pruriens var. utilis considering the leaflet size, though, it is cultivated. The three taxa are closely related in their leaflet shape, surface and arrangement which are deltoid, glabrous and alternate respectively (Tables 1 and 2). There were striking differences on the testa colour and petals of the three taxa. The testa colour as stated on the Table 1 and shown in Fig 1 , may be a result of their genetic make-up, environment and anthocyanin in the taxa. Our findings disagree with the report of Lampariello et al. (2012) that the velvet bean has long, slender branches; alternate, lanceolate leaves; and white flowers with a bluish-purple, butterfly-shaped corolla. Its pods oare pubescent. The disagreement in our reports may as a result of environmental factors at the locations of our studies. This study has unveiled characteristics of the three taxa of Mucuna for prospective researchers to really ascertain the main source of the natural levodopa. It can be concluded that, morphological characters primarily important in Mucuna taxonomy.

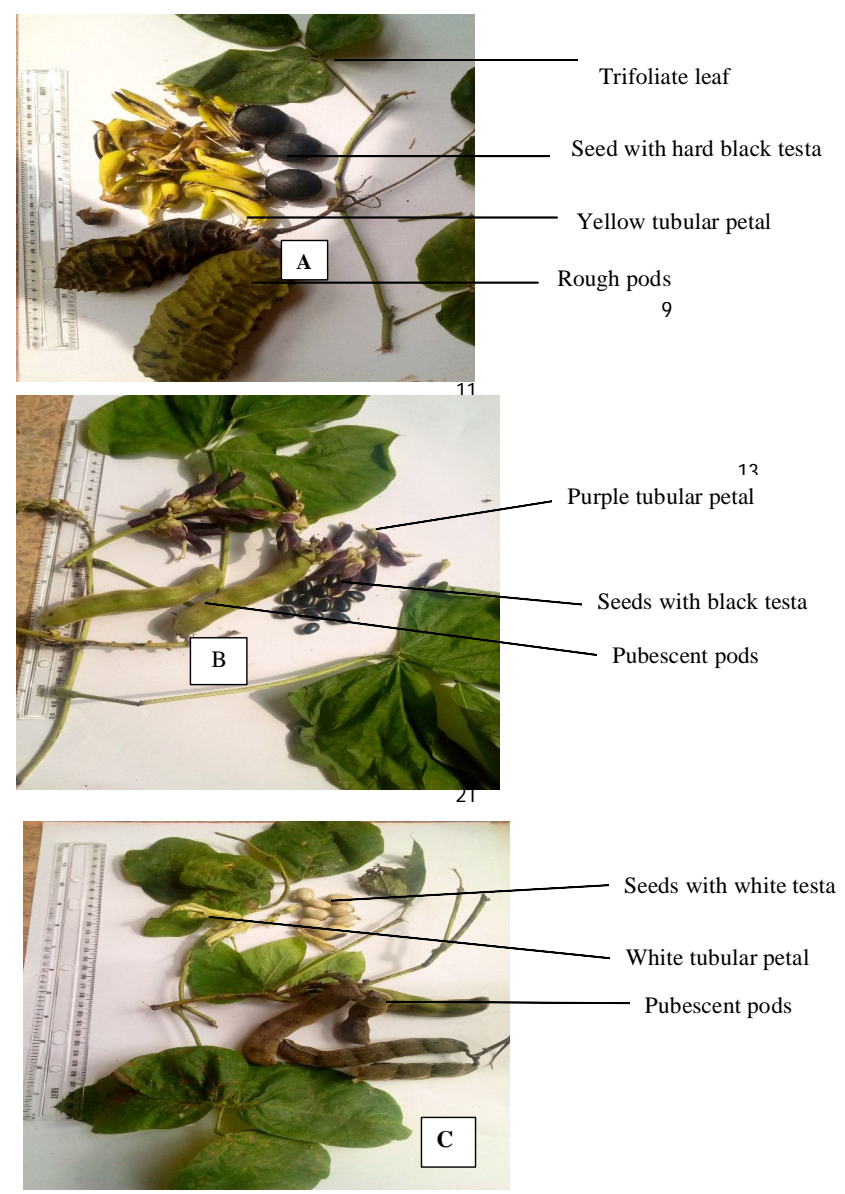

Fig 1: Photographs of the three taxa of Mucuna. A: M. flagellipes.

B: M. pruriens var. pruriens. C: $M$. pruriens var. utilis.

Table 1: Qualitative morphological characters of the three taxa of Mucuna.

\begin{tabular}{|c|c|c|c|c|c|c|c|c|c|}
\hline Taxon $\quad$ Character & $\begin{array}{l}\text { Leaflet } \\
\text { type }\end{array}$ & $\begin{array}{l}\text { Leaflet } \\
\text { shape }\end{array}$ & $\begin{array}{l}\text { Leaflet } \\
\text { margin }\end{array}$ & $\begin{array}{l}\text { Leaflet } \\
\text { apex }\end{array}$ & $\begin{array}{l}\text { Leaflet } \\
\text { base }\end{array}$ & $\begin{array}{l}\text { Leaflet } \\
\text { surface }\end{array}$ & $\begin{array}{l}\text { Petal } \\
\text { colour }\end{array}$ & $\begin{array}{l}\text { Teata } \\
\text { colour }\end{array}$ & $\begin{array}{c}\text { Pod } \\
\text { surface }\end{array}$ \\
\hline M. flagellipes & Trifoliate & Deltoid & Entire & Acute & Truncate & Glabrous & Yellow & Black & Rough \\
\hline M. pruriens var. pruriens & Trifoliate & Deltoid & Entire & Acute & Oblique & Glabrous & Purple & Black & Pubescent \\
\hline M. pruriens var. utilis & Trifoliate & Deltoid & Entire & Acute & Truncate & Glabrous & White & White & Pubescent \\
\hline
\end{tabular}

Table 2: Quantitative morphological characters of the three taxa of Mucuna.

\begin{tabular}{lcccc}
\hline & Leaf length $(\mathrm{cm})$ & Leaf width $(\mathrm{cm})$ & Internode length $(\mathrm{cm})$ & Petiole length $(\mathrm{cm})$ \\
\hline M. flagellipes & $6.4(9.5 \pm 0.20) 11.2$ & $4.1(6.8 \pm 1.1) 8.3$ & $12.0(10.2 \pm 0.2) 18.2$ & $7.1(9.8 \pm 1.1) 12.3$ \\
$M$. pruriens var. pruriens & $13.0(17.5 \pm 0.1) 24.1$ & $10.8(12.3 \pm 0.4) 14.2$ & $15.3(13.9 \pm 0.2) 22.4$ & $10.1(12.8 \pm 0.1) 16.3$ \\
M. pruriens var. utilis & $9.0(8.4 \pm 0.1) 13.2$ & $3.0(4.9 \pm 0.2) 9.2$ & $10.4(11.9 \pm 0.2) 14.0$ & $8.0(7.3 \pm 0.1) 9.3$ \\
\hline
\end{tabular}




\section{CONCLUSION}

The similarities in the structures of the taxa showed that they are related to be in the same genus while few differences among them show their existence as a distinct species. Petal and testa colour could be used to distinguish three taxa studied. The three taxa studied are edible when they are well treated. There is a need to properly identify the species and varieties of Mucuna before carrying out research on them.

\section{REFERENCES}

Adebowale, K.O. and Lawai, O.S. (2005). Variability in the physicochemical and anti-nutritional attributes of six Mucuna species. Food Chemistry. 89: 37-48.

Afolabi, O.A., Oshuntogun, B.A., Adewusi, S.R., Fapojuwo., O.O., Ayorinde, F.O., Grisson, F.E. and Oke, O.L. (1985). Preliminary nutritional and chemical evaluation of raw seeds from Mucuna solanei: An underutilized food source. Journal of Agricultural Food Chemistry. 33: 122-124.

Agharkar, S.P. (1991). Medicinal Plants of Bombay Presidency. Scientific Publ. Jodhpur. India. p. 1-2.

Buckles, D. (1995). Velvetbean: A new plant with a history. Economic Botany. 49: 13-25.

Carsky, R.J., Tarawali, G., Becker, M., Chikoye, D., Tian, G. and Sanginga, N. (1998). Mucuna-herbaceous cover legume with potential for multiple uses. Resource and Crop Management Research Monograph No. 25. International Institute of Tropical Agriculture (IITA), Ibadan, Nigeria.

De Moura, T.M., Wilmot-Dear, M., Vatanparast, M., Fortuna-Perez, A.P., Ana M.G.A. Tozzi, A.M.GA. and Lewis, GP. (2016). A New Infrageneric Classification of Mucuna(LeguminosaePapilionoideae): Supported by Morphology, Molecular Phylogeny and Biogeography. Systematic Botany. 41(3): 606-616.

Eilittä, M., Muinga, J., Mureithi, R., Sandoval, C. and Szabo, N. (2003). Increasing Mucuna's Potential as A Food and Feed Crop. Proceedings of An International Workshop, Mombasa, Kenya, September 23-26, 2002.

Enwere, J.N. (1998). Food of Plant Origin. Nsukka: Afrobis Publ. Ltd., pp. 2-20.

Ene-obong, H.N. and Corovale, E. (1992). Nigerian soup condiments: Traditional processing and potential as dietary fibre source. Food Chemistry. 43: 29-34.

Ezeagu, L.E., Mazya-Dixon, B. and Tarawali, G. (2003). Seed characteristics and nutrients and anti-nutrient composition of six Mucuna species from Nigeria. Tropical and Subtropical Agro Ecosystem. 1: 129-140.

Ezueh, M.I. (1997). Cultivation and Utilization of Minor Food Legumes in Nigeria. Tropical grain Legumes Bulletin 10, International Institute for Tropical Agriculture, Ibadan, Nigeria.

Farooqi, A.A., Khan, M.M. and Asundhara, M. (1999). Production Technology of Medicinal and Aromatic Crops. Natural Remedies Pvt. Ltd., Bangalore, India. p. 26-28.

Gilbert, R. (2002). Mucuna pruriens in Malawi: A Promising Legume with A Troubled History. In: Food and Feed from Mucuna: Current Uses and the Way Forward, Workshop, CIDICCO, CIEPCA and World Hunger Research Center, Tegucigalpa, Honduras. Pp 48-59.

Infante, M.E., Perez, A.M., Simao, M.R., Manda, F., Baquete, E.F. and Fernandez, A.M. (1990). Outbreak of acute psychosis attributed to Mucuna pruriens. Lancet. 336: 1129.
Lampariello, L.R., Cortelazzo, A., Guerranti, R., Sticozzi, C. and Valacchi, G. (2012). The magic velvet bean of Mucuna pruriens. Journal of Traditional and Complementary Medicine. 2(4): 331-339.

Maldonado, R.G. (2018). Mucuna and Parkinson's Disease: Treatment with Natural Levodopa, intechopenLicensee InTech. Pp 6 -23.

Natarajan, K., Narayanan, N. and Ravichandran, N. (2012). Review on "Mucuna" the wonder plant. International Journal of Pharmaceutical Sciences Review and Research. 17(1): 86-93.

Nwankwo, O.E and Ayodele, A.E. (2017) Taxonomic studies of the genus Indigofera linn., in Nigeria, International Digital Organisation. Journal for Scientific Research. 2 (3): 10-26.

Onuegbu, N.C., Nworah, K.O., Essien, P.E., Nwosu, J.N. and Ojukwu, M. (2013). Proximate, functional and antinutritional properties of boiled Ukpo seed (Mucuna flagellipes) flour. Nigerian Food Journal. 31(1): 1-5.

Osei-Bonsu, P., Buckles, D., Soza, F.R. and Asibuo, J.Y. (1996). Edible cover crops. ILEIA Newsletter. 12: 30-31.

Pandey, U. (1999). Chamatkari Paudhe. Bhagwati Pocket Books, Agra, India.

Ravishankar, R.P., Kiran, D.P., Manali, R.R., Shrirang, R.Y., Vishwas, A.B. and Jyoti, P.J. (2016). Assessment of genetic diversity of in Mucuna species in India using randomly amplified polymorphic DNA and Inter simple Sequence repeat markers. Journal of Physiology and Molecular Biology of Plants. 22(2): 207-217.

Shalini, K. (1997). Vedic Leguminous Plants. Classical Publ. Co., New Delhi.

Shashtry, R.K. (1995). Bhartiya Jabi-butiyon tatha vrikcho ke chamatkar. Dehati Pustak Bhandar, Delhi.

Singh, U., Wadhwani, A.M. and Johri, B.M (1996). Dictionary of Economic Plants in India. Indian Council of Agricultural Research, New Delhi. p. 45-146.

Tozzi, A.M.G.A, Agostini, K. and Sazima, M. (2005). A new species of Mucuna Adans. (Leguminosae, Papilionoideae, Phaseoleae) from southeastern Brazil, with a key to Brazilian species. Taxon. 54: 451-455.

Ukachukwu, S.N. and Obioha, F.C. (2000). Effect of time duration of thermal treatments on the nutritive value of Mucuna cochinchinensis. Global Journal of Pure and Applied Science. 6: 11-15.

Ukachukwu, S.N. and Obioha E.C. (1997). Chemical evaluation of Mucuna cochechinensis as an alternative protein feedstuff. Journal of Applied Chemistry and Agric. Research. 4: 43-48.

Ukachuwu, S.N., Ezeagu, I.E., Tarawali, G. and Ikeorgu, J.E.G. (2002). Utilization of Mucuna as a Food and Feed in West Africa. In: Food and Feed from Mucuna: Current Uses and the Way Forward [Editors, Flores, B.M., Eilittä, M., Myhrman, R., Carew, L.B. and Carsky, R.J.], Workshop, CIDICCO, CIEPCA and World Hunger.

Upadhyay, R.K. (2000). Upyogi Jadi-Butiyan. Randhir Prakashan, Haridwar, India.

Vadivel, V. and Janadhanan K. (2000). Nutritional and antinutritional composition of velvet bean, an underutilized food legume in South India. International Journal of Food Sciences and Nutrition. 51: 279- 287.

Wilmot-Dear, C.M. (1984). A Revision of Mucuna (LeguminosaePhaseoleae) in China and Japan. Kew Bulletin. 39: 23-65. 